\title{
Soil Organic Carbon in the Arid Regions (A Brief Overview of Iran)
}

\author{
Bijan Azad* \\ Department of Rehabilitation of Arid and Mountainous Regions, University of Tehran, Iran \\ *Corresponding author: Bijan Azad, Department of Rehabilitation of Arid and Mountainous Regions, Faculty of Natural Resources, \\ University of Tehran, Tehran 31587-77871, Iran
}

\section{Introduction}

Soils are the largest organic carbon pool in terrestrial ecosystems, the quantity of this pool is twice the amount of organic carbon in the atmosphere and three times more organic carbon than the biotic world [1]. Soils store an estimated 1500Pg organic carbon in the first meter of soil and 2500Pg of organic carbon to $2 \mathrm{~m}$; which is more organic carbon than is contained in the biotic world (500Pg of carbon) and twice as much organic carbon as the atmosphere (750Pg of carbon) [2]. Recently studies reported that any small changes in the soil organic carbon (SOC) will have a major impact on the concentration of $\mathrm{CO}_{2}$ in the atmosphere as well as global warming. Therefore, soils have a prominent role in maintaining the balance of the global carbon cycle. Soils of arid regions make an important contribution to global SOC stock (roughly one third) and climate change mitigation. Based on the mean annual rainfall, regions receiving $200-500 \mathrm{~mm}$ of winter rainfall are defined arid and in other words, it can be said areas where average rainfall is less than the potential moisture losses through evaporation and transpiration [3]. Arid regions account for $40 \%$ of the world's land (approximately 430 million ha), and they are particularly valuable for SOC sequestration due to their high extent, and also their high degree of permanence (long-term SOC storage). In arid region ecosystems the poor vegetation cover, the low concentration of litter, the sparse vegetation, and the low biodiversity of plant species, lead to low SOC content [4]. The soils of arid regions mainly due to low organic carbon content (less than $1 \%$ of the soil mass), large surface area, and long residence time of SOC have a special place to sequester more SOC [5].

The soil potential for SOC sequestration is related to maximum carbon stabilization capacity (carbon saturation of soil) [6]. Reported that soils of arid regions are far from saturated mainly due to their low plant production capability and aridity. Water scarcity in arid regions constrains plant productivity and, on another hand, the residence time of carbon in these regions is much longer due to their aridity. In general, desirable and undesirable properties affecting soil carbon storage and soil carbon sequestration in arid regions are presented in Table 1, [7]. Increasing SOC storage in arid regions may require major changing ecosystem conditions for example by the cultivation of plants resistant to water stress and high-temperature compatible plants or by using irrigation, etc. However, most arid regions are in developing countries (about $72 \%$ ) and given the lack of proper facilities and poor management, there is still a long way to go to improve soil carbon storage in arid regions. About $90 \%$ of Iran's land area located in the arid and semiarid regions of the country. The most important characteristic of arid regions of Iran include high evaporation rate, low rainfall, long dry periods, lack of soil development, wind and water erosion, severe changes in temperature between night and day, scarcity of surface water and groundwater resources, high concentration of minerals limiting plant growth (gypsum, lime, salt), and sandstorms.

Table 1: Desirable and undesirable properties for soil carbon sequestration in Arid regions [7].

\begin{tabular}{|c|c|}
\hline Undesirable & Desirable \\
\hline Water scarcity & \multirow{2}{*}{ Long residence time of SOM } \\
\hline Low and irregular rainfall & \\
\hline High temperature & \multirow{2}{*}{ High surface area } \\
\hline Low plant production capability & \\
\hline Low soil fertility & \multirow{2}{*}{$\begin{array}{l}\text { High potential in SOC } \\
\text { sequestration }\end{array}$} \\
\hline $\begin{array}{c}\text { Soil susceptible to erosion and } \\
\text { desertification }\end{array}$ & \\
\hline
\end{tabular}

Additionally, arid regions of Iran are susceptible to different types of land degradation including wind erosion and water erosion, soil salinity, soil alkalization and some practices of human-induced soil degradation such as over-grazing, off-road vehicles, and et. All of the degradation processes mentioned will ultimately deplete the soil organic carbon pool in arid regions of Iran. Therefore, arid rangelands of Iran need to be sustainably managed to maintain their existing SOC levels and increase their SOC sequestration potential. In arid regions of Iran with harsh environmental conditions, plants regenerate less and their establishment through seeding, shrub and 
seedling planting is not simple. Therefore, plants must be selected according to the following criteria [8]:

a. Compatible with drought and severe changes in temperature;

b. Resistance to salinity and alkaline soils, having a deep and strong root system;

c. Having water storage potential in shoots;

d. Having strong organs;

e. Having extensive and dense canopy.

The effect of various factors and processes on SOC content in arid regions of Iran has not been adequately quantified, though arid regions occupy a vast land area of the country and might play the main role in climate change mitigation through carbon sequestration in soils. In recent years, some researchers have studied the effects of climate change, grazing, and water and wind erosion on soil carbon content at the site scale in Iran [9-12]. However, these studies are not sufficient and due to the high area of arid regions of Iran and the various processes of degradation in arid regions of the country, detailed studies on the effects of wind erosion and the introduction of resistant and adapted plant species to the Iranian dry conditions are needed.

\section{References}

1. Lal R (2009) Sequestering carbon in soils of arid ecosystems. Land Degradation. Development 20(4): 441-454.
2. FAO, ITPS (2015) Status of the World's Soil Resources.

3. FAO (2004) Carbon sequestration in dryland soils, FAO, Rome, Italy.

4. Montané F, Romanyà J, Rovira P, Casals P (2010) Aboveground litter quality changes may drive soil organic carbon increase after shrub encroachment into mountain grasslands. Plant Soil 337(1): 151-165.

5. United Nations (2011) Global drylands: A UN system-wide response. s.l.: United Nations Environment Management Group.

6. Beare M, Mcneill S, Curtin D, Partt R, Jones H, et al. (2014) Estimating the organic carbon stabilization capacity and saturation deceit of soils: A New Zealand case study. Biogeochemistry 120(1-3): 71-87.

7. Azad B (2015) Soil organic carbon dynamic modelling. M.Sc. thesis in Desert Region Management. Faculty of Agriculture, Shiraz university, Shiraz, Iran.

8. Jafari M, Tavili A, Panahi F, Zandi Esfahan E (2018) Reclamation of Arid Lands. Springer International Publishing 273.

9. Afzali SF, Azad B, Golabi MH, Francaviglia R (2019) Using RothC Model to Simulate Soil Organic Carbon Stocks Under Different Climate Change Scenarios for the Rangelands of the Arid Regions of Southern Iran. Water 11(10): 1-13.

10. Azad B, Afzali SF (2018) Modelling the impacts of climate change on the soil $\mathrm{CO}_{2}$ emissions in arid rangelands (Southern Iran). Desert Ecosystem Engineering Journal 7(20): 71-87.

11. Faghihinia M, Afzali, SF (2013) Effects of wind erosion on soil organic carbon dynamics and other soil properties: Dejgah catchment, Farashband County, Shiraz Province, Iran. African Journal of Agricultural Research 8(34): 4452-4459.

12. Azad B, Afzali SF (2019) Evaluation of Two Soil Carbon Models Performance Using Measured Data in Semi-arid Rangelands of Bajgah, Fars Province. Iranian Journal of Soil and Water Research 50(4): 819835.

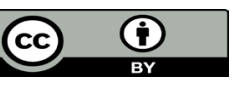

This work is licensed under Creative Commons Attribution 4.0 License

To Submit Your Article Click Here:

Submit Article
DOI: $10.32474 /$ CIACR.2019.07.000272

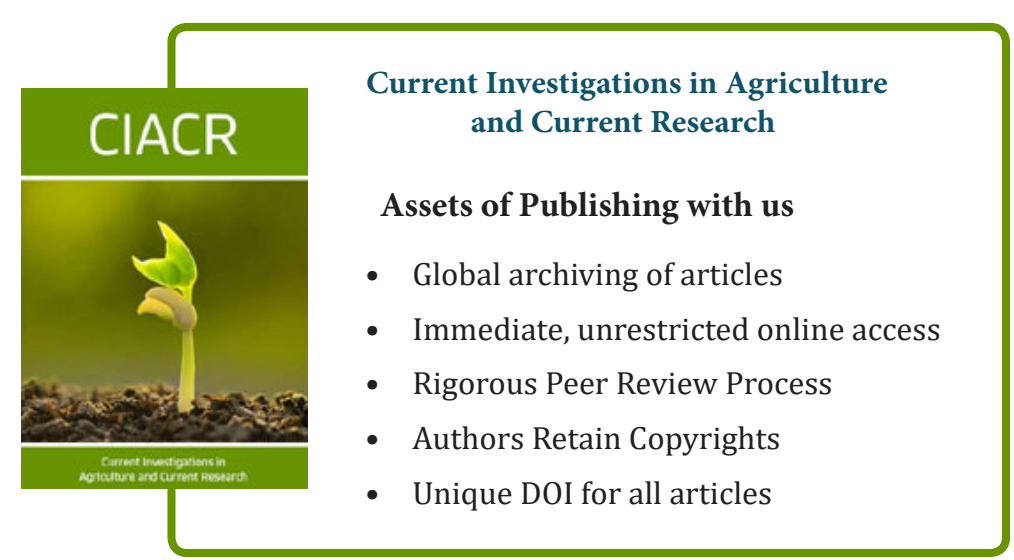

